\title{
Studies on Harvesting and Threshing Parameters of Available Tractor Operated Groundnut Digger-Shaker and Fresh Pod Thresher
}

\author{
B. Vennela*, C. Ramana, M.V. Ramana, S. Joseph Reddy, \\ S. Kalleemullah and K. Lavanya Kumari \\ CAE, Bapatla, India \\ *Corresponding author
}

\begin{tabular}{|l|}
\hline Ke y w o r d s \\
Harvesting, \\
Threshing \\
parameters, \\
Groundnut \\
Digger-Shaker \\
\hline Article Info \\
\hline $\begin{array}{l}\text { Accepted: } \\
\text { 25 October } 2018 \\
\text { Available Online: } \\
\text { 10 November } 2018\end{array}$ \\
\hline
\end{tabular}

\section{Introduction}

Groundnut or peanuts is a species in the legume or "bean" family. The peanut was probably first domesticated and cultivated in the valleys of Paraguay. It is an annual herbaceous plant growing 30 to $50 \mathrm{~cm}$ tall. Peanuts are known by many other local names such as earthnuts, ground nuts, goober peas, monkey nuts, pygmy nuts and pig nuts.

\begin{abstract}
Groundnut is an important oil seed crop in India cultivated in an area of 6.7 million hectares with a production of 7.0 million tonnes annually. The crop can be grown successfully in areas receiving the rainfall ranging from 600 to $1250 \mathrm{~mm}$. The best soils for groundnut crop are sandy loam, loam and medium black with good drainage system. Present practice of manual harvesting and threshing consumes huge amount of labour to a magnitude of about 175 to 200 women $\mathrm{h} \mathrm{ha}^{-1}$ The highest average effective field capacity obtained using tractor drawn groundnut digger shaker was $0.35 \mathrm{ha} \mathrm{h}^{-1}$. The highest average field efficiency of $80.10 \%$ recorded for tractor drawn groundnut digger shaker at a soil moisture content of $12 \%$. The low values obtained for both average effective field capacity and field efficiency of the tractor drawn groundnut digger shaker as a result of the turning and other miscellaneous losses. The haulm yield of the windrows formed for a harvested distance of $10 \mathrm{~m}$ was $1.011 \mathrm{~kg}$ for single row, $2.128 \mathrm{~kg}$ for two rows and $3.518 \mathrm{~kg}$ for three rows. Performance of wetpod thresher selected for a design was observed at feed rate of $870 \mathrm{~kg} \mathrm{~h}^{-1}$ and the thresher output was $227.25 \mathrm{~kg} \mathrm{~h}^{-1}$ with the total number of labourer of 6 . Similarly in case of manual stripping output was only $51.13 \mathrm{~kg} \mathrm{~h}^{-1}$ with the equal number of labourer. Therefore, it was found that output capacity of selected thresher was 4 times more than the manual stripping with equal number of labour requirement.

A B S T R A C T
\end{abstract}

Despite its name and appearance, the peanut is not a nut, but rather a legume. India is the second largest producer of groundnuts in the world in the order shown in the table 1. Indian groundnuts are available in different varieties as bold or Runner, Java or Spanish and Red Natal. The major growing state for groundnut is Gujarat, Andhra Pradesh, Tamil Nadu, Karnataka, Maharashtra Rajasthan, Madhya Pradesh, Orissa, and Uttar Pradesh. 
At present there is a lack of workers in the field of agriculture and due to more cost in harvesting. Due to the above factors, farmers are not involved in groundnut cultivation. The removing of groundnut pods is a time consuming process and cost expensive. Temperature is very high at harvesting time so people finds difficult to work. To overcome these difficulties groundnut thresher is used in groundnut pod removing process which minimize the time and cost. The major reasons for the demand for groundnut machinery are to reduce drudgery, to improve timeliness, and to increase productivity and income. The most desirable machines indicated by farmers are stripper, digger, and planter for irrigated area; planter, stripper, and weeder for rainfed area; and stripper, weeder, and seed shelter for area using residual soil moisture (Chinsuwan et al., 1991).

Harvesting of groundnut has always been laborious and associated with a high level of drudgery to accomplish harvesting tasks. Determining when to harvest is important. Okello et al., (2013) stated that farmers might gain up to $300-450 \mathrm{~kg} / \mathrm{ha}$ of groundnuts and $2-3 \%$ in standards around the ten (10) day period before desirable harvest. If groundnut is not harvested at its favourable state of maturity losses greater than $300-450 \mathrm{~kg} / \mathrm{ha}$ could ensue.

Regular checking of groundnut is important to determine the harvesting period. Groundnut maturity affects grade, flavour, quality of milling, and storage life. Groundnuts harvested at the exact due date stage, is of premium quality to the producer, aside meeting the required consumer characteristics. During the process of harvesting, extreme caution is required so as not to damage the pods; as such, a situation could ensue in contamination by Aspergillus parasiticus or Aspergillus flavus culminating in aflatoxin pollution (Okello et al., 2013).

\section{Materials and Methods}

The present study is conducted at Madakasira, which is located in Anantapur district of Andhra Pradesh.The Madakasira region is considered as one of the arid areas with low precipitation of $532 \mathrm{~mm}$.A field of 0.27 ha area was selected for the present study;most of the madakasira region is characterized by sandy loam soils with gravel.

\section{Study of windrows formed by digger shaker}

When the digger shaker was used for harvesting, the harvested crop material was dropped and directed through rear fenders to form a windrow, the material need to be collected from these windrows. Hence to study the physical characteristics of the windrows, certain observations were made by varying the blade orientation and total width. The procedure adopted for studying the windrows as follows. For the study three rows were selected namely single row, double row and triple row. Each of these rows was harvested by digger shaker by adjusting the blade of the digger shaker in order to harvest the selected number of rows. The crop material fallen on the ground for single row, double row and triple row was weighed separately for a $10 \mathrm{~m}$ of run and also the crop material dropped at different speeds for the selected rows was also measured.

Tractor was used for drawing the groundnut digger shaker implement. A total area of 0.27 hectares of sandy loam soil was used for the study. The field was divided into three different experimental plots with each plot having a dimension of $30 \mathrm{~m}$ by $30 \mathrm{~m}$ and trials were carried out. This was done to assess the crop quantity or volume per each row at the time of harvesting so as to synchronize with the threshing input requirement of the machine. Crop was sown with recommended row spacing $30 \mathrm{~cm}$ and $10 \mathrm{~cm}$ intra row 
spacing. The same field was utilized to study performance of the developed machine. The soil moisture content was determined using the digital moisture meter. The speed of operation for the developed machine was determined by taking the average time it took the tractor to cover the known distance. The time factors (such as actual time, obstruction time and turning time) which were used for determining the total time for completing each tillage operation was measured with a stop watch. A $1 \mathrm{~m}^{2}$ square rod frame was used as marked area for taking samples of harvested groundnut plant, unharvest groundnut plant, damaged groundnut pods, exposed groundnut pods, detached groundnut pods lying exposed, detached groundnut pods inside the soil that fell within the $1 \mathrm{~m}^{2}$ marked area on each selected pot. The samples from these selected plots were used to assess the performance of the tractor drawn groundnut digger shaker.

\section{Test parameters for selected digger shaker}

Five samples were taken from each of the plot, where parameters such as percentage exposed, buried, damaged, etc., were used for the computation of the machine losses, digging efficiency.

i) Total quantity of pods $\mathrm{A}=\mathrm{B}+\mathrm{C}$

ii) Percentage of damaged pods $=\frac{\mathrm{C}}{\mathrm{A}} \times 100$

iii) Percentage of exposed pod loss $=\stackrel{\frac{\mathrm{G}}{\mathrm{A}}}{\times 100}$

iv) Percentage of buried pod loss $=\frac{\mathrm{H}}{\mathrm{A}} \times 100$

v) Percentage of undug pod loss $=\frac{\mathrm{K}}{\mathrm{A}} \times 100$

vi) Digging Efficiency $=100-$ Total percentage of pod loss

Total $\%$ of pods loss $=\%$ of exposed pods loss $+\%$ of unexposed pods loss $+\%$ of undug pods loss

Where,

$\mathrm{A}=$ total quantity of pods collected from the plant in the sampled area.

$\mathrm{B}=$ quantity of clean pods collected from the plant dug in the sampled area, exposed pods lying on the surface and the buried pods.

$\mathrm{C}=$ quantity of damaged pods collected from the plants in the sampled area.

$\mathrm{G}=$ quantity of detached pods lying exposed on the surface.

$\mathrm{H}=$ quantity of detached pods remained inside the soil in the sampled area.

$\mathrm{K}=$ quantity of pods remaining undetached from the undug plants in the sampled area.

\section{Study of wet pod thresher}

Thresher selected for study consists of frame, feed hopper, drum type threshing cylinder, concave, oscillating sieves and a blower. Total construction mounted on the main frame (specifications given in Table 2.). The threshing cylinder had the diameter and length of $50 \mathrm{~cm}$ and $90 \mathrm{~cm}$, respectively. The cylinder surface was provided with flat pegs arranged in 6 rows such that each row has $7-$ 8 pegs (length of peg $10 \mathrm{~cm}$ ). A concave was provided under the threshing cylinder for rough separation of pods and stripped plants. An outlet was provided at the rear portion of cylinder for stripped plants. In order to separate all the unwanted material after threshing from the pods, two sieves were provided below the concave. The top sieve had perforations of $50 \times 17 \mathrm{~mm}$ size and the bottom sieve had perforations of $25 \times 9 \mathrm{~mm}$ size(Reddy et al., 2013). A centrifugal blower with spiral casing has been provided in between the two cleaning sieves for blowing 
of light weight plant material coming along with threshed pods from the concave. Crop flow diagram for threshing in wet pod thresher was shown in Fig 1

A popular variety of groundnut K6 freshly harvested crop was used for threshing and pod to haulm ratio was noted. The blower speed was maintained to develop a velocity slightly less than terminal velocity of groundnut pods for separation of stripped plants, leaves and other foreign material from pods (Padmanathan, 2006). The cylinder and blower speeds were measured by using a digital non - contact type tachometer and the feed rate was measured by using a platform balance. A stop watch was used to note the time of operation. Windrows of groundnut crop made by digger shaker was used as material to study the test parameters and three samples were taken from each of the plot threshed with selected wet pod thresher, where parameters such as percentage of broken pods, un detached pods, time taken etc., was used for the computation of the machine losses, cleaning efficiency and threshing efficiency of the machine.

\section{Threshing efficiency}

This was taken as the ratio of weight of pods collected from all outlets per unit time and weight of input pods per unit time.

$\mathrm{E}_{\mathrm{t}}=\frac{W_{0}}{W_{1}} \times 100$

Where,

$\mathrm{E}_{\mathrm{t}}=$ Threshing efficiency, per cent

$\mathrm{W}_{0}=$ Weight of pods collected from all outlets per unit time, $\mathrm{kg}$

$\mathrm{W}_{1}=$ Weight of input pods per unit time

\section{Cleaning efficiency}

This was taken as the ratio of difference between weight of pods and weight of foreign matter collected from main outlet per unit time and weight of pods collected from main outlet per unit time.

$\mathrm{E}_{\mathrm{c}}=\frac{W_{m}-W_{f}}{w_{m}} \times 100$

Where,

$\mathrm{E}_{\mathrm{c}}=$ Cleaning efficiency, per cent

$\mathrm{W}_{\mathrm{m}}=$ Weight of pods collected from main outlet per unit time, $\mathrm{kg}$

$\mathrm{W}_{\mathrm{f}}=$ Weight of foreign matter collected from main outlet per unit time, $\mathrm{kg}$

\section{Percentage of broken pods}

This was taken as the ratio between weight of broken pods collected from main outlet per unit time and weight of input pods per unit time.

$\mathrm{B}_{\mathrm{p}}=\frac{W_{b}}{W_{\mathrm{i}}} \times 100$

Where,

$\mathrm{B}_{\mathrm{p}}=$ Percentage of broken pods, per cent

$\mathrm{W}_{\mathrm{b}}=$ Weight of broken pods collected from main outlet per unit time, $\mathrm{kg}$

$\mathrm{W}_{\mathrm{i}}=$ Weight of input pods per unit time

\section{Results and Discussion}

The performance of digger shaker was done as explained in above and the results were presented in Table: 1 which includes all the test parameters. Results of the harvesting operation carried out on the groundnut crop at 120 days after planting using the tractor drawn digger shaker at $12 \%$ soil moisture content at different field trials were presented.

From Table 3 the highest average digging efficiency recorded for tractor drawn groundnut digger shaker was $89.66 \%$ occurred at soil moisture content of $12 \%$. The highest average effective field capacity obtained using tractor drawn groundnut digger shaker was 0.36 ha h $^{-1}$. 
Table.1 Specifications of Digger Shaker

\begin{tabular}{|l|l|}
\hline Specification & Details \\
\hline Length $(\mathbf{m m})$ & 2050 \\
\hline Width $(\mathbf{m m})$ & 2100 \\
\hline Height $(\mathbf{m m})$ & 1150 \\
\hline Type & Mounted implement \\
\hline Weight $(\mathbf{k g})$ & 300 \\
\hline Power requirement $(\mathbf{h p})$ & 35 and above, tractor \\
\hline Capacity (ha day $\mathbf{- 1}^{-1}$ & 2 \\
\hline Length of blade(mm) & $5 \mathrm{~mm}$ thick x 100 mm wide x 180 mm length \\
\hline Angle of blade (degrees) & 50 \\
\hline Uses & $\begin{array}{l}\text { For harvesting and windrowing groundnut crop } \\
\text { at soil moisture levels of } 8 \text {-15\% dry basis. }\end{array}$ \\
\hline
\end{tabular}

Table.2 Specifications of wet pod thresher

\begin{tabular}{|c|c|}
\hline Parameters & Details \\
\hline $\begin{array}{l}\text { Power source Tractor } \\
\text { Power transmission }\end{array}$ & $\begin{array}{l}\text { PTO shaft of speed } 540 \text { RPM } \\
\text { Telescopic universal joint }\end{array}$ \\
\hline Overall dimensions of the thresher & $\begin{array}{l}\text { Length } 3850 \mathrm{~mm} \\
\text { Width } 1450 \mathrm{~mm} \\
\text { Height } 2680 \mathrm{~mm}\end{array}$ \\
\hline $\begin{array}{l}\text { Threshing cylinder } \\
\text { Type } \\
\text { Diameter } \\
\text { Length } \\
\text { Concave } \\
\text { Inner diameter } \\
\text { Grate opening size } \\
\text { Clearance }\end{array}$ & $\begin{array}{l}\text { Drum type having pegs on its periphery } \\
470 \mathrm{~mm} \\
900 \mathrm{~mm} \\
250 \mathrm{~mm} \\
80 \times 30 \mathrm{~mm} \\
40 \mathrm{~mm}\end{array}$ \\
\hline $\begin{array}{l}\text { Cleaning sieves } \\
\text { No. of sieves } \\
\text { Sizes of sieves } \\
\text { Top sieve } \\
\text { bottom sieve }\end{array}$ & $\begin{array}{l}2 \\
50 \times 17 \mathrm{~mm} \\
25 \times 9 \mathrm{~mm}\end{array}$ \\
\hline $\begin{array}{l}\text { Blower diameter } \\
\text { No. of paddles in blower } \\
\text { No. of transport wheels }\end{array}$ & $\begin{array}{l}600 \mathrm{~mm} \\
4 \\
2\end{array}$ \\
\hline Cost of machine & Rs. $1,50,000 /-$ \\
\hline
\end{tabular}


Table.4 Haulm yield at different rows for $10 \mathrm{~m}$ of run

\begin{tabular}{|l|l|l|l|l|l|}
\hline Sl.no & No of rows & R1 & R2 & R3 & Average Haulm yield $(\mathbf{g})$ per 10 m run \\
\hline $\mathbf{1}$ & Single row & 2884.54 & 3012.45 & 2912.53 & 2936.50 \\
\hline $\mathbf{2}$ & Two rows & 6235.25 & 6345.82 & 6585.24 & 6388.77 \\
\hline $\mathbf{3}$ & Three rows & 8569.23 & 8757.14 & 8685.57 & 8670.64 \\
\hline
\end{tabular}

Table.4 Observations during field test of groundnut digger shaker

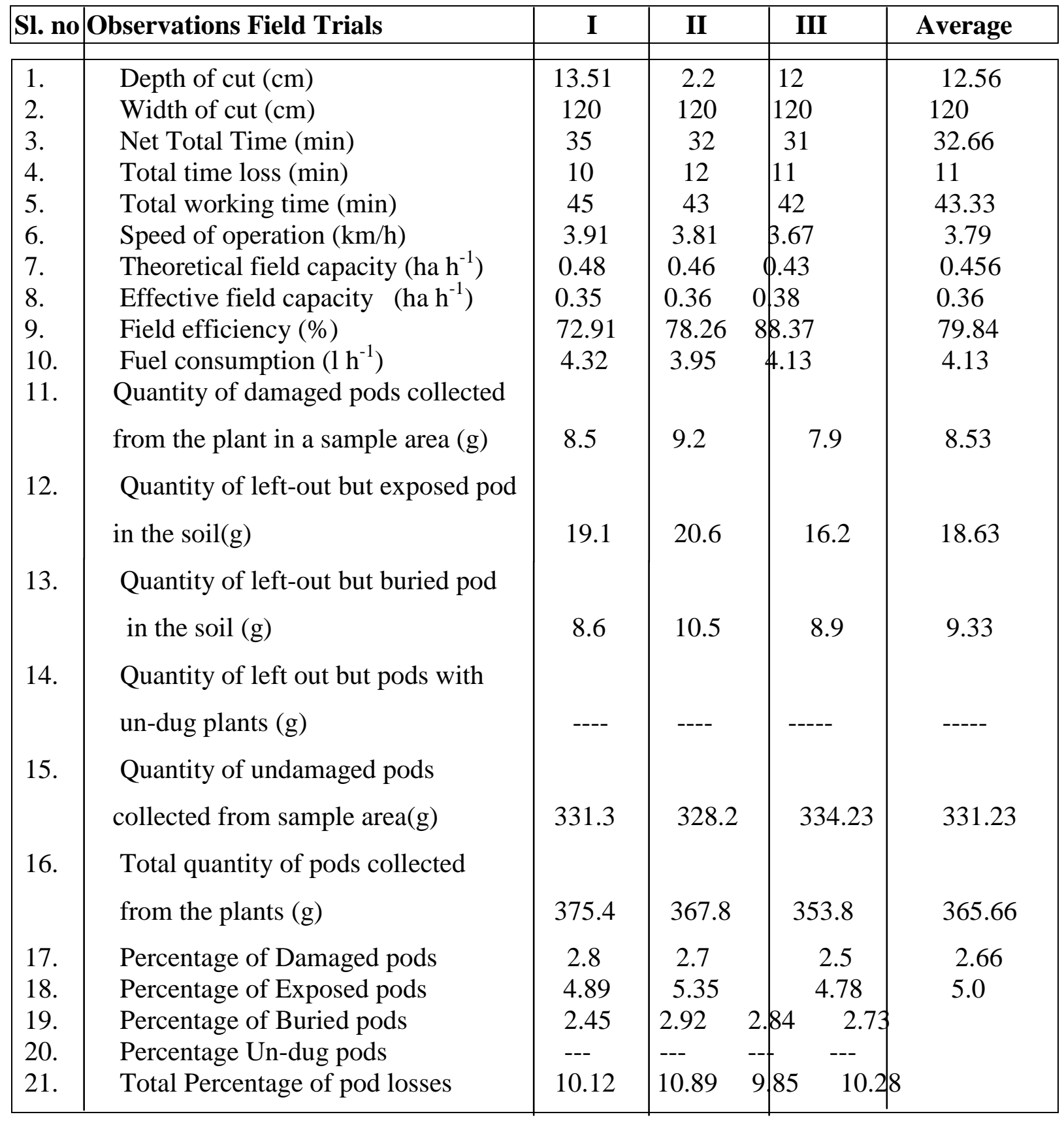

Digging Efficiency (\%) 
Table.5 Performance evaluation of wet pod thresher

\begin{tabular}{|c|c|c|c|c|}
\hline \multirow[t]{2}{*}{ Parameters } & \multicolumn{4}{|c|}{ Machine threshing } \\
\hline & $\mathbf{R} 1$ & $\mathbf{R 2}$ & $\mathbf{R 3}$ & AVG \\
\hline 1. Feed rate of crop, $\mathbf{~ k g h}^{-1}$ & 872.23 & 878.12 & 865.57 & 871.97 \\
\hline 2. Cylinder speed, RPM & 285 & 285 & 285 & 285.00 \\
\hline 3. Blower shaft speed, RPM & 760 & 760 & 760 & 760.00 \\
\hline 4. No. of labour required & 7 & 7 & 7 & 7 \\
\hline $\begin{array}{l}\text { Man-h required to thresh } \\
\text { one ha area of groundnut } \\
\text { crop }\end{array}$ & 48.15 & 46.24 & 49.83 & 48.07 \\
\hline 6. Output capacity, $\mathbf{k g ~ h}^{-1}$ & 230.54 & 235.87 & 215.35 & 227.25 \\
\hline 7. Threshing efficiency, $\%$ & 96.12 & 95.86 & 97.57 & 96.51 \\
\hline 8. Cleaning efficiency, $\%$ & 98.24 & 96.12 & 97.58 & 97.31 \\
\hline $\begin{array}{l}\text { 9. Percentage of broken pods, } \\
\%\end{array}$ & 1.76 & 3.88 & 2.42 & 2.68 \\
\hline
\end{tabular}

Plate.1A Images of digger shaker windrower

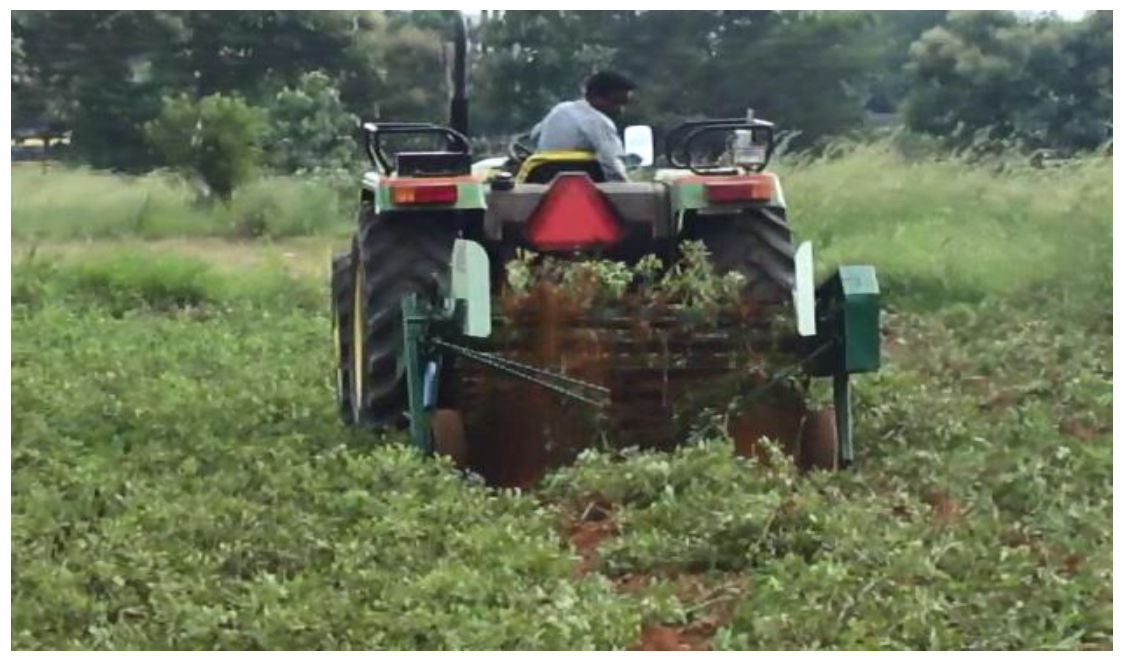

A 
Plate.1B Images of digger shaker windrower

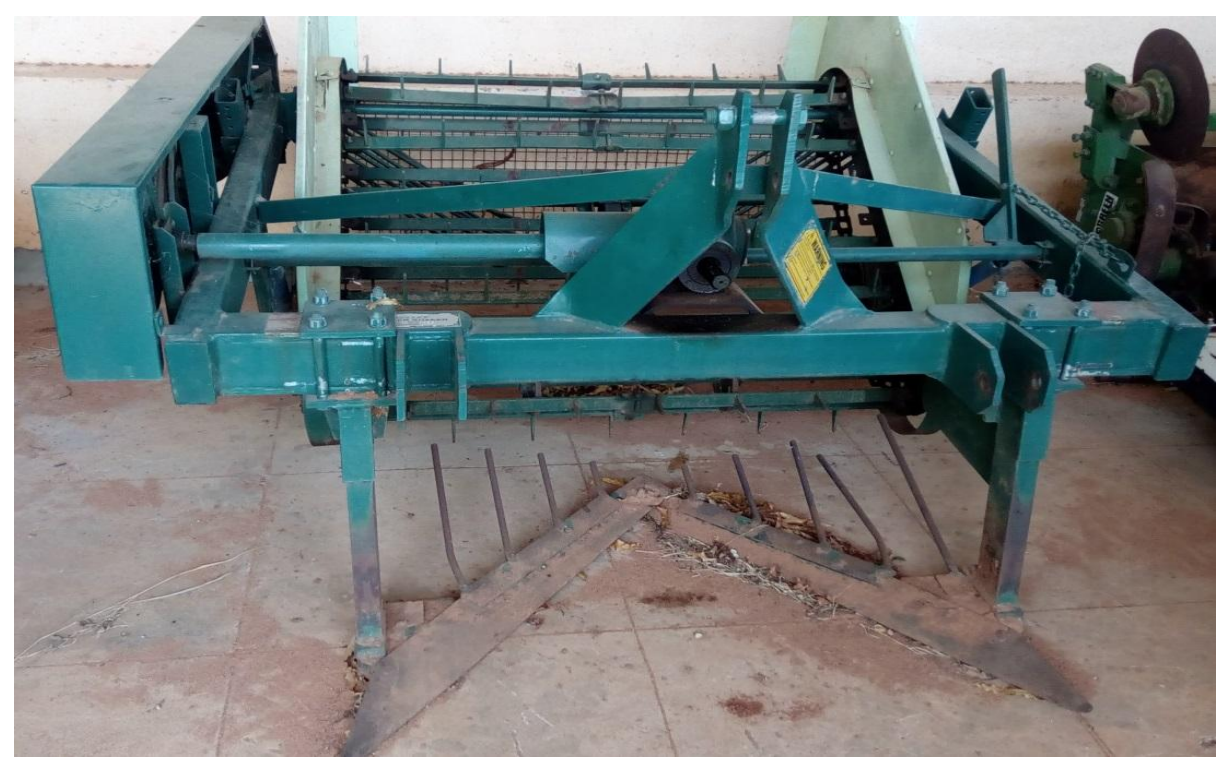

Figure.1 Crop flow diagram for threshing freshly harvested groundnut crop

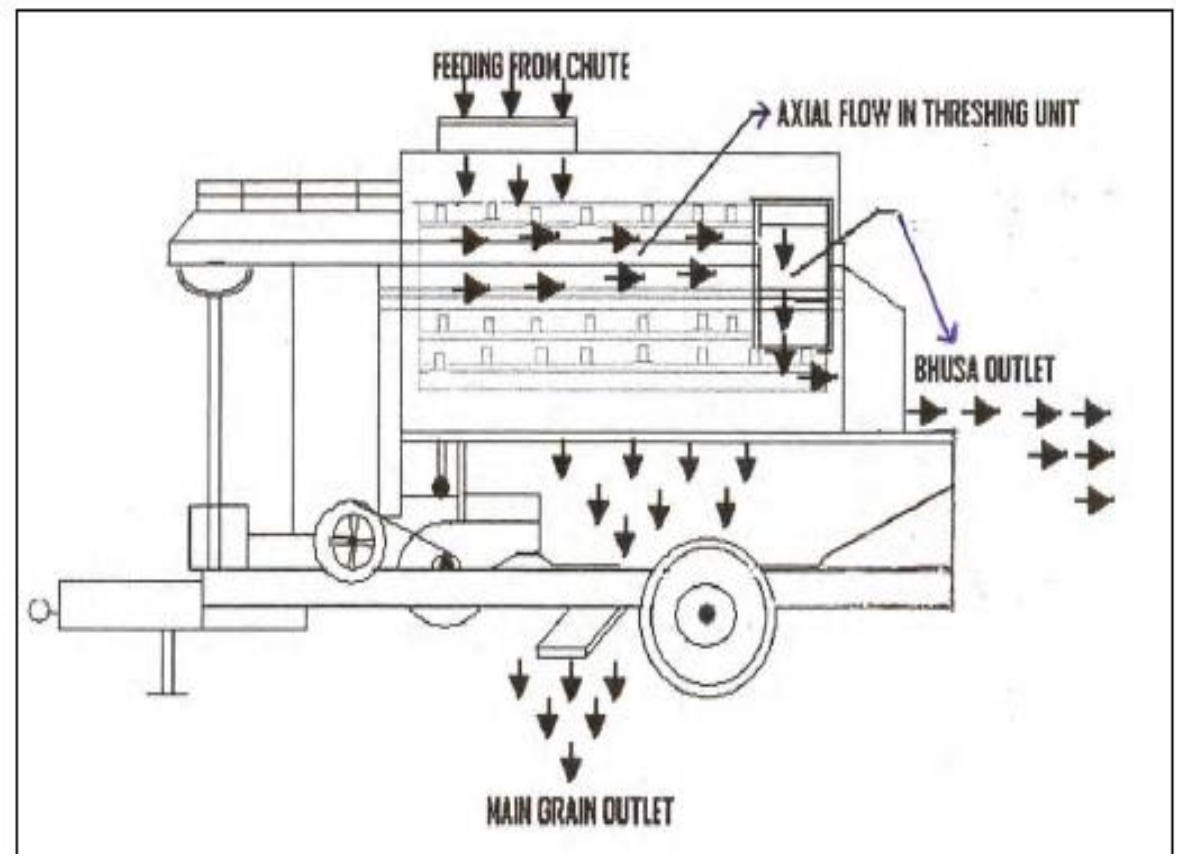

The effective field capacity of digger shaker was in the range of 0.35 to $0.37 \mathrm{ha} \mathrm{h}^{-1}$ with an average of 0.36 ha $\mathrm{h}^{-1}$ (Vagadia et al., 2015). Indicatively, mechanized pulling and windrowing of the plants requires about $4-6$ working hours per hectare. Picker-threshers usually finish the work of the above machines by gathering up the windrows for threshing (De Lucia and Assennato, 1994).

The highest average field efficiency of $79.84 \%$ recorded for tractor drawn groundnut 
digger shaker occurred at a soil moisture content of $12 \%$. The low values obtained at $12 \%$ in other replications for both average effective field capacity and field efficiency of the tractor drawn groundnut digger shaker was as a result of the turning and other miscellaneous losses.

\section{Study of windrows formed by digger shaker}

Windrows formed by digger shaker were calculated as explained in above. From the Table 4the results revealed that the haulm yield of the windrows formed for a distance of $10 \mathrm{~m}$ was $2936.50 \mathrm{~g}$ for single row, $6388.77 \mathrm{~g}$ for two rows and $8670.64 \mathrm{~g}$ for three rows. The results observed that as increase in the number of rows haulm yield increased. By using the haulm yield the design of lateral conveyor was done.

\section{Performance evaluation of wet pod thresher}

Crop parameters observed during threshing was plant height was $35.68 \mathrm{~cm}$ with the average number of filled pods of 20.04 per plant and average the pod-vine ratio was noted as 1:4 for the K6 variety of groundnut.Results obtained from the experimental field evaluation were shown in Table 5. It was observed that at the feed rate of $870 \mathrm{~kg} \mathrm{~h}^{-1}$, the thresher output capacity was $227.25 \mathrm{~kg} \mathrm{~h}^{-1}$ with the total number of labour of 7. On comparing it was found that output capacity of selected thresher was 4 times more than the manual stripping with equal number of labour requirement which was similar to the results obtained by Reddy et al., 2013.

\section{References}

De Lucia, M., and Assennato, D. (1994). Agricultural engineering in development. Post-harvest operations and management of food grains.FAO Agricultural Services Bulletin.No. 93. Rome

Okello, D. K., Monyo, E., Deom, C. M., Ininda, J., and Oloka, H. K. (2013). Groundnuts production guide for Uganda: Recommended practices for farmers. Entebbe, Uganda: National Agricultural Research Organisation

Padmanathan, P.K., Kathivel, K., Manian, R. and Duraisamy, V.M.2006. Design, development and evaluation of tractor operated groundnut combine harvester. Journal of Applied Research. 2(12): 1338-1341

Reddy, K.M., Kumar, B., Reddy, R. and Reddy, B.S. 2013. Performance evaluation of groundnut thresher for freshly harvested crop. International Journal of Agricultural Engineering 6(1): 67-70

Vagadia, V.R., Bhutada, S., Memon, A.H. and Yadav, R. 2015. Development and testing of tractor drawn groundnut digger-shaker.An International $\quad e$ Journal 4(4): 369-379.

\section{How to cite this article:}

Vennela, B., C. Ramana, M.V. Ramana, S. Joseph Reddy, S. Kalleemullah and K. Lavanya Kumari. 2018. Studies on Harvesting and Threshing Parameters of Available Tractor Operated Groundnut Digger-Shaker and Fresh Pod Thresher. Int.J.Curr.Microbiol.App.Sci. 7(11): 35173525. doi: https://doi.org/10.20546/ijcmas.2018.711.401 